\title{
Analysis and Application of River Surface Line in Hilly Area based on Hec-ras Model
}

\author{
Congshan Yang ${ }^{1,2}$, Ming $\mathrm{Lu}^{1}$ and Guifeng $\mathrm{Li}^{3}$ \\ ${ }^{1}$ College of hydroelectric engineering, Hebei University of Engineering, Handan 056001, China \\ ${ }^{2}$ Handan water conservancy and Hydropower Survey and Design Research Institute, Handan 056001, China \\ ${ }^{3}$ Handan water conservancy and Hydropower Construction Co., Ltd, Handan 056001, China
}

\begin{abstract}
For example - Cixian Fuyang River Regulation Project. Due to the character that Fuyang River is located in hilly areas of Cixian, we use the Hex-ras software to calculate the status of the river water surface line for the goal of determining the final treatment plan. We maintain the present situation of the river channel design as principle, select the most appropriate pushed water level and roughnessas the basic, and we combine the classification calculation of crossing structures of backwater and the encryption calculation section to get the more accurate result.We compare the water level elevation and the calculation of cross strait, analyze the design parameters, calculate repeated the water line section, analyze the rationality of the design plan, and then finally determine the applicability of Hex-rac software in the large continuous variation of cross section of embankment of river river surface line.
\end{abstract}

Keywords. Hilly area river, Water surface line calculation, hec-ras software, CSonstant flow, Roughness.

\section{Introduction}

In mountainous and hilly areas due to the river on both sides of the ground ladder structure, the embankment is not continuous, the river section or in a single section without beach land, or in a compound section with separating channel and beach, flood water surface width is not the law of the state, the method for determining the effective water line, is the priority among priorities of governance the river. The calculation methods of regular river surface line include graphic method and trial by trial method [1-7]. For the river with large cross-section change and steep slope in the hilly area, some unreasonable results may appear due to the above calculation. Wang Han, TianFamei et al., carry out the effective water surface line analysis of the gradually expanding river by improving the kinetic energy correction coefficient [8]. By establishing the variable step difference model, Qi Feng makes a high precision water line calculation for the river with large cross section,solves practical engineering problems [9], Lin Jinsong adopted the method of prediction correction to solve the problem of discontinuity calculation of water surface line under the complicated terrain conditions, such as positive slope and reversed slope, frequent expansion and sudden contraction [10].

\section{Mathematical model and governing equation}

The Hec-ras software is used to establish one-dimensional unsteady flow model, taking CixianFuyang River treatment project as an example, by changing the section parameters, analyze the change of water surface line and rules repeatedly, verify the reliability design. Hec-ras is the United States Army Corps of Engineers and one of the development of river simulation computer software, can be used to simulate constant calculation of unsteady flow, river flow and sediment 
transport calculation, steady flow, unsteady flow in river water line calculation [11]. Constant flow calculation principle based on one-dimensional energy equation, by section were calculated by direct method. In the calculation of constant water surface line, the formula is:

$$
Z_{2}+\frac{a_{2} v_{2}^{2}}{2 g}=Z_{1}+\frac{a_{1} v_{1}^{2}}{2 g}+\mathrm{h}_{f}+\mathrm{h}_{i}
$$

In the formula, $Z_{1}, Z_{2}$ is the downstream and upstream section of the water level elevation, $a_{1}, a_{2}$ is the downstream and upstream section of the velocity coefficient, $v_{1} 、 v_{2}$ is the downstream and upstream section of the velocity; g is gravity acceleration; and $\mathrm{h}_{f} 、 \mathrm{~h}_{i}$ for upstream and downstream section of the frictional head loss and the local water head loss [12].

\section{Engineering survey}

Cixian Fuyang started from Cixian Dongwushi Hydropower Station tailrace outlet, in Qinglan high-speed into the city of Handan within the length of Cixian River $26.1 \mathrm{Km}$. The scope of governance for the Beijing Guangzhou railway upstream of the river $5 \mathrm{~km}$, calculate the range to the upper section of the water control $1 \mathrm{~km}$ line. The purpose of governance is mainly through the channel dredging water serious place, does not meet the requirements of the high embankment of hilling, so as to meet the requirements of flood. In addition, the main building is three governance wading bridge, are the main factors causing backwater height, so the surface line calculation process need to increase the calculation of the three seat wading bridge.

\section{Calculation parameters}

\subsection{Governance standards:}

In 20 years the standard of flood control engineering calculation and analysis of river water line, according to the hydrological calculation, Cixian Fuyang River section of each hydrological results are shown in Table 1. The control section of the river is located in the upper reaches of interval Longwangmiao to Cixian railway bridge, so 20 years once the design flow using $174 \mathrm{~m}^{3} / \mathrm{s}$.

Table 1. The peak flow results. $\quad \mathrm{m}^{3} / \mathrm{s}$

\begin{tabular}{lcrr}
\hline Section & $\begin{array}{l}10 \\
\text { years }\end{array}$ & $\begin{array}{r}20 \\
\text { years }\end{array}$ & $\begin{array}{r}50 \\
\text { years }\end{array}$ \\
\hline $\begin{array}{l}\text { Maximum } \\
\text { reservoir } \\
\text { discharge }\end{array}$ & 50 & 51 & 450 \\
$\begin{array}{l}\text { The Dragon King } \\
\text { Temple ditch after }\end{array}$ & 85 & 174 & 451 \\
$\begin{array}{l}\text { import } \\
\text { The railway near } \\
\text { the peak flow }\end{array}$ & 110 & 215 & 731 \\
\hline
\end{tabular}

\subsection{Roughness coefficient:}

The roughness is the primary index to reflect river resistance, roughness selection directly affects the level of water flow rate, the size is an important factor affecting the water surface line calculation, in general, to determine the roughness of the need to repeatedly the natural river roughness should be solved according to the traffic data of the measured water level, or on the surface the measured line or flood investigation of water trace backstepping roughness [13]. According to 
the measured data, the water level of the corresponding pile number is compared with the measured water level through the selection of different roughness. The smaller the difference, the more reasonable the roughness selection is. This project due to the measured water level, so take this period of Fuyang governance adjacent segments roughness calculation, calculation of water surface profile of river cross section, channel roughness at the rate of $0.045,0.06$ of the beach roughness selection, after treatment of river cross section calculation of water surface profile, roughness of channel 0.03 , the beach roughness coefficient unchanged.

\subsection{Initial water level:}

There is a range of influence of initial water level of the river to the river water level, general engineering design, the corresponding water level method or the highest water level method [14], when the channel is computed without measured data, by the control of downstream buildings (such as gates, weirs) to determine the control level, control of downstream buildings can be extended a distance,to the downstream river, the critical water depth as the downstream water depth control [15], because of the lower reaches of the river section has been governance, so the downstream water level control of the water level upstream has been calculated as the water surface line calculation.

\subsection{Section selection:}

At present, the main vector in flood period is calculated as the distance between two sections. Hilly area of river section mutation, dike is not continuous, in fact the flood and the main channel spacing is not uniform spacing [16], consider the main channel bend, using HEC-RAS software surface line calculation, the appropriate channel change area encryption section, can make the result more reasonable, the water surface line calculation process, using section spacing $50 \mathrm{~m}$.

\subsection{Backwater height calculation of buildings across the river:}

The present situation of the channel involving a total of three bridges, a highway bridge, two water bridges, the energy loss of buildings caused by wading river is divided into three parts in the software, the first part is the building occupancy wading flow section so that the upstream flow energy loss caused by energy loss; second part caused by contraction the water flow through the building after wading diffusion; third part for a variety of shape and arrangement of the building itself by wading [17-18]. The calculation of water diffuse bridge backwater, weir flow coefficient, entrance loss coefficient and wall roughness has a significant influence on the calculation results, the weir flow coefficient $\mathrm{C}$ is the result of the most sensitive parameters [19], therefore, choose a reasonable $\mathrm{C}$ value of backwater calculation is essential.

\subsection{Computing method:}

The establishment of system layer, draw the river curve from upstream to downstream and save the data, the result shown in Figure 1; Input the measured cross-section parameters in sequence and save it; add upstream section and downstream section fot every bridge, input current parameters of wading bridges, establish the boundary conditions, according to the classification of wading bridges, selectthe corresponding flow calculation method, according to the constant flow calculation process, input the flow and initial water level, then it can be calculated. 


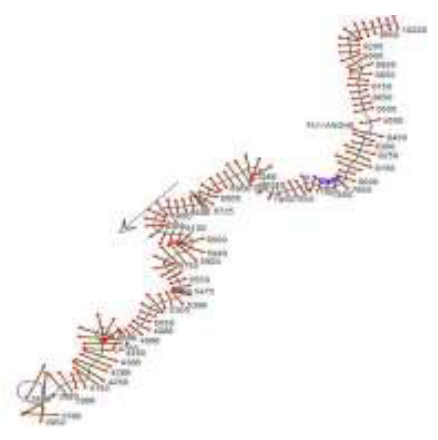

Fig.1. River Map.

\section{Result analysis}

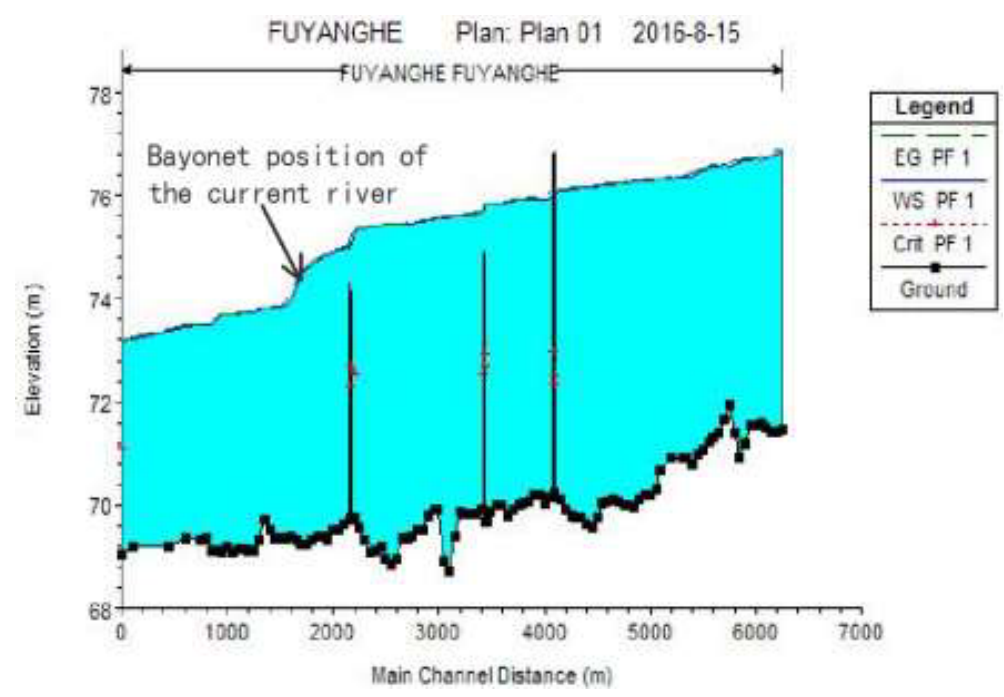

Fig.2. Longitudinal profile of current river surface line.

We can see from Figure 2, two bridges through the village have been completely submerged and the water level was raised, the highway bridge backwater height is small, Cross section of water of water bridge and cross river bridge can be seen in Figure 3 and Figure 4. In addition, in two km water suddenly increased by $90 \mathrm{~cm}$, the main reason is because of the serious $200 \mathrm{~m}$ river siltation, narrow river channel, the bayonet, raise the water level directly determines the upper reaches of the river flood control capacity on both sides of the embankment, so it is necessary to compare the 20 year flood level and the status quo of estuary embankment elevation or the current channel,calculation result in Table 2.

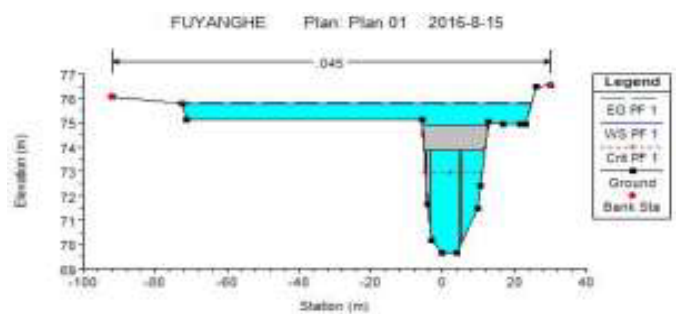

Fig.3. Cross flow section of a water bridge. 


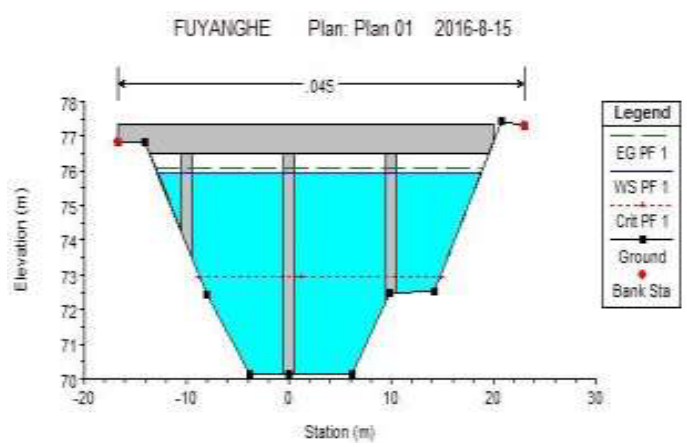

Fig.4. Cross flow section of Cross River Bridge.

Table 2. Current river level reference.

\begin{tabular}{|c|c|c|c|c|c|c|c|}
\hline position & $\begin{array}{l}\text { Flow } \\
\left(\mathrm{m}^{3} / \mathrm{s}\right)\end{array}$ & $\begin{array}{c}\text { Thestatus } \\
\text { quo of river } \\
\text { bottom } \\
\text { elevation }(\mathrm{m})\end{array}$ & $\begin{array}{l}\text { Status flood } \\
\text { level (m) }\end{array}$ & $\begin{array}{l}\text { Status quo of } \\
\text { left } \\
\text { embankment } \\
\text { elevation (m) }\end{array}$ & $\begin{array}{l}\text { Status quo of } \\
\text { right } \\
\text { embankment } \\
\text { elevation (m) }\end{array}$ & $\begin{array}{l}\text { Current Speed } \\
(\mathrm{m} / \mathrm{s})\end{array}$ & $\begin{array}{c}\text { Water } \\
\text { surface width } \\
(\mathrm{m})\end{array}$ \\
\hline $7+400$ & 174 & 70.25 & $7 \lessdot .03$ & 77.29 & 77. 28 & 1. 19 & 32.23 \\
\hline $7+397$ & 174 & \multicolumn{6}{|c|}{ Cross River Bridge of Xiang Shuiliang village } \\
\hline $7+3\lceil 0$ & 174 & 70.14 & 75.93 & 76.81 & $77.4 c_{5}$ & 1.38 & 31.65 \\
\hline $6+8\ulcorner 0$ & 174 & 70 & 75.86 & 76.00 & 75.35 & 0.48 & 110.2 \\
\hline $6+800$ & 174 & c9. 86 & 75.85 & 75.80 & 75.35 & 0.54 & 119.3 \\
\hline$\sigma_{5}+745$ & 174 & 69.65 & 75.77 & 75.11 & 75.11 & 1.22 & 97.14 \\
\hline $6+725$ & 174 & \multicolumn{6}{|c|}{ Water bridge of Li Zhuang village } \\
\hline $6+720$ & 174 & 9.91 & 75.60 & 75.11 & 75.11 & 0.86 & 188.9 \\
\hline $6+700$ & 174 & 89.91 & 75.65 & 76.11 & 75.44 & 0.53 & 189.9 \\
\hline $5+550$ & 174 & 69. 56 & 75.35 & 74.75 & 74.83 & 0.7 & 135 \\
\hline $5+500$ & 174 & 99.76 & 75.3 & 74.79 & 74.24 & 0.92 & $14 C .1$ \\
\hline $5+475$ & 174 & \multicolumn{6}{|c|}{ Water bridge of Bai Jiazhuagn village } \\
\hline $5+450$ & 174 & c9.73 & 75.01 & 75.25 & 74.82 & 0.98 & 118.7 \\
\hline $3+9\lceil 0$ & 174 & 8.35 & 73.45 & 73.65 & 73. 39 & 0.8 & 99.77 \\
\hline $3+88$ r & 174 & 6.21 & 73. 39 & 73.65 & 73. 54 & 0.72 & 111.2 \\
\hline $3+78 c$ & 174 & 9.05 & 73. 17 & 73. 57 & 73.45 & 0.74 & 110.9 \\
\hline
\end{tabular}

After the calculation of river governance ultra-high not less than $1 \mathrm{~m} \mathrm{[20].} \mathrm{Can} \mathrm{be} \mathrm{seen} \mathrm{from} \mathrm{table} \mathrm{2,} \mathrm{ultra} \mathrm{high}$ embankment are not almost intact to meet the requirements of flood control, embankment need to be filled; and surface width is large, most houses on both sides of the river will be flooded, considering the difficulty and investment immigration control, at the same time in order to keep the original river flow state, the initial design scheme is to design wide river close to the current width of $12 \mathrm{~m}$ principle, longitudinal slope design close to the status of bottom slope is 0.00057 , taking the slope of 1:2 on the narrow channel dredging cut slope, for the status quo is wider, the bottom section of the deeper, to maintain the status quo, not backfill. Design plan water surface profile in Figure 5, elevation contrast result in Table 3. 


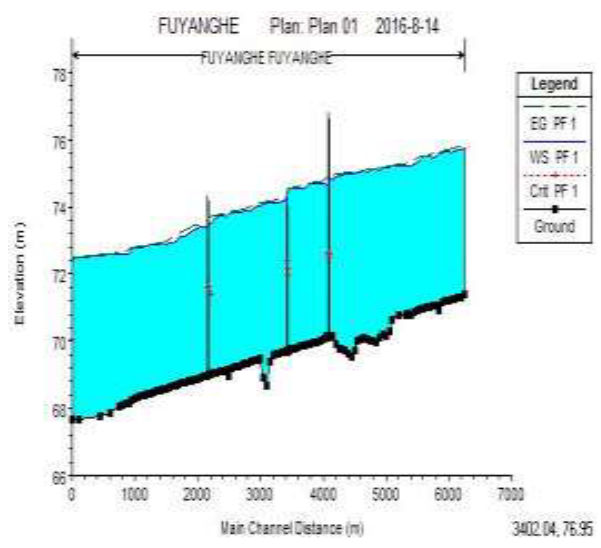

Fig.5. Longitudinal profile of river surface design.

Figure 5 shows that the river water is basically uniform trend, three bridges include only a water bridge, and the backwater height is obvious, but the backwater height does not affect the effect of flood control embankment upstream. The water level rising caused by the channel status of the bayonet region through dredging excavation, water level dropped to normal range. Table 3 shows, after dredging the river, flood situation is significantly reduced,the status of banks in addition to the local high position slightly lower, the vast majority of all meet the requirements of flood control,so We only need to add a heightened local bank; compared to the previous status of the speed increased, the calculation of scour depth is less than $1.5 \mathrm{~m}$, the maximum velocity at $1.99 \mathrm{~m} / \mathrm{s}$, the dangerous position of the scour depth is less than $1 \mathrm{~m}^{20}$, so we just have to scour the dangerous position to take the masonry lining erosion prevention measures. The results show that the design scheme is reasonable, without debugging, on the contrary, we need to further debug the design parameters, repeatedly calculate the water line, so that the program in the construction and engineering benefits to achieve the best.

Table 3. Design river level reference.

\begin{tabular}{|c|c|c|c|c|c|c|c|}
\hline position & $\begin{array}{l}\text { Flow } \\
\left(\mathrm{m}^{3} / \mathrm{s}\right)\end{array}$ & $\begin{array}{l}\text { The } \\
\text { designed } \\
\text { bottom } \\
\text { elevation } \\
\text { (m) }\end{array}$ & $\begin{array}{c}\text { Designed } \\
\text { flood } \\
\text { level (m) }\end{array}$ & $\begin{array}{l}\text { Status quo } \\
\text { of left } \\
\text { embankment } \\
\text { elevation } \\
\text { (m) }\end{array}$ & $\begin{array}{l}\text { Status quo } \\
\text { of right } \\
\text { embankment } \\
\text { elevation } \\
\text { (m) }\end{array}$ & $\begin{array}{c}\text { Current } \\
\text { Speed }(\mathrm{m} / \mathrm{s})\end{array}$ & $\begin{array}{r}\text { Water } \\
\text { surface } \\
\text { width (m) }\end{array}$ \\
\hline $7+400$ & 174 & 70.12 & 74.79 & 77.29 & 77.28 & 1. 64 & 32.73 \\
\hline $7+397$ & 174 & Cross River & Bridge of $X$ & Iang Shuiliar & g village & & \\
\hline $7+350$ & 174 & 70. 14 & 74.67 & 76.81 & 77.40 & 1.82 & 30.14 \\
\hline $5+850$ & 174 & 8.79 & 74.56 & $7 C .00$ & 75.35 & 0.75 & 103.9 \\
\hline$c+800$ & 174 & 9.76 & 74.54 & 75.80 & 75.35 & 0.82 & 88.14 \\
\hline $6+745$ & 174 & 69.7 & 74. 42 & 75.11 & 75.11 & 1. $5_{3}$ & 33.71 \\
\hline $5+725$ & 174 & \multicolumn{6}{|c|}{ Water bridge of Li Zhuang village } \\
\hline$c+720$ & 174 & 89.73 & 74.14 & 75.11 & 75.11 & 1.99 & 30.84 \\
\hline+700 & 174 & 69.7 & 74.22 & $7 c_{0} .11$ & 75.44 & 1.08 & 115.2 \\
\hline $5+550$ & 174 & 9.04 & 73.62 & 74.75 & 74.83 & 1.45 & 2.06 \\
\hline $5+500$ & 174 & 9.01 & 73. 5 & 74.79 & 74.24 & 1.75 & 33.1 \\
\hline $5+475$ & 174 & \multicolumn{6}{|c|}{ Water bridge of Bai Jiazhuagn village } \\
\hline $5+450$ & 174 & 8.98 & 73.43 & 75.25 & 74.82 & 1.83 & 34.3 \\
\hline $3+9\lceil 0$ & 174 & 67.85 & 72.59 & 73. 65 & 73. 39 & 0.46 & 374.2 \\
\hline $3+88 c$ & 174 & 87.77 & 72.5 & 73.65 & 73.54 & 0.51 & $22^{2.2}$ \\
\hline $3+786$ & 174 & 67.65 & 72.45 & 73. 57 & 73.45 & 0.81 & 174.6 \\
\hline
\end{tabular}




\section{Conclusion}

(1)core work of the hilly area river is the calculation of water surface profile, which directly determines the size of the project, investment size, but because of the characteristics of ladder type hilly landform, the river section width disparity, embankment height fluctuation, it is difficult to determine the flow range, so the traditional method of water surface line calculation is the difficulty of river control in Hilly Area, Hec-ras software in the establishment of one dimensional unsteady flow model, through the simple steps will increase the river section, avoid the influence of frequent changes of water level caused by river section, the flow pattern changes in the river can be reflected in the calculation.

(2)According to the classification of water diffuse buildings and buildings across the river, the choice of formula of different simulation of wading structure calculation of backwater height, improve the accuracy of the design water level, the water line interface is reasonable, more important, which makes the design height of embankment is more accurate, to the requirements for flood control is more safe and reliable, fully applicable in the hilly area of discontinuous embankment, steep longitudinal slope, the river water dense buildings.

\section{References}

1. Liu Yang. Comparison of several surface line calculation method. Yellow River,2011,33(2):51-53 .( in Chinese).

2. Huang Yousheng. A new calculation method of water surface line.Development of water conservancy and Hydropower Science and technology, 2003, 23(3): 31-33.( in Chinese) .

3. Zhang Jianmin, Wang Yurong,Xu Weilin, et al.An iterative method for the calculation of constant gradient flow.Journal of hydraulic engineering,2005, 36(4):501-503. ( in Chinese) .

4. Lei Fengze,Shi Xiangling. Analysis and analysis of water surface line calculation in design of embankment engineering.China water transport, 2007,5 (6) : 83-84. ( in Chinese).

5. Wu Chigong.Hydraulics.Beijing:Higher Education Press,2008. (in Chinese) .

6. Gao Huanzhi,Qin Jianping,Li Ting, et al.Calculation of natural water surface of river channel in engineering design.Inner Mongolia Water Resources, 2014,4:32-33. ( in Chinese) .

7. Song Tao.Study on influence of river channel change on water surface line.School of architecture and engineering, Nanchang University, 2013. ( in Chinese).

8. Wang Han,Tian Famei,Lv Hongxing.Calculation and improvement of the water surface line of the gradual expansion of the mountainous area. Yellow River, 2007,29(5):66-67. ( in Chinese) .

9. Qi Feng.Calculation of river water surface line based on variable step difference iterative method. Yangtze River, 2015,46(1):83-85. ( in Chinese) .

10. Lin Jinsong,Ju Jiang,Zhang Kuandi, et al.Calculation of natural river surface line under complex terrain.Journal of Northwest Agriculture and Forestry University (Natural Science Edition),2010. (in Chinese) .

11. Ye Nan,Zhang Wei,Bai Zhongliang. Application of HEC-RAS software in small and medium river harnessing project in mountainous area .Computer application, 2013,3:70-73. ( in Chinese) .

12. Liu Yang,Sun Xiaoying, Qang Junying, et al.Calculation of water surface line of natural river in mountainous area by HEC-RAS and SOBEK-RURAL software.Beijing Water, 2008,6:34-36. ( in Chinese) .

13. Yao Zhiqiang,GU Hehe.MapInfo land use status thematic map digital production.Resource development and market, 2007,23( 12):1067-1069.( in Chinese) .

14. Chen Biao,Chen Changbai.Analysis and determination of the influence of water level on the water surface of the river.Science and Technology Forum, 2009:21-22. (in Chinese) .

15. Zhu Zhonglong.Determination of the water level in the calculation of the water surface line of natural river.Construction and Engineering, 2014,28(4):448-449. ( in Chinese) . 
16. Tian Fengjun,Ji Zhongguang,Liu Yuxia. Discussion on some problems in the calculation of the water surface line of rivers.Heilongjiang water conservancy science and technology, 1999,2:41-43. ( in Chinese) .

17. Wang Xiaoyang,Deng Zanxin,Yu Weihou.Hec-ras model and its application in water resistance in the calculation of the high bridge.Hunan Hydro \& Power,2008,3:31-32. ( in Chinese) .

18. Liu Zhengfeng,He Runjin,Li Wenxiang.The application of HEC RAS model of continuous bridge backwater high resistance analysis.Water conservancy science and technology, 2011, $3: 60-61$. (in Chinese) .

19. Yang Yang,Han Fengxia,Liu Junmei, et al.Computation of water surface line of mountain river and culvert bridge backwater. Yellow River, 2013, 35(1):123-125. ( in Chinese).

20. Code for design of embankment engineering, GB 50286-2013. ( in Chinese) . 